e ISSN-0976-7223 | Visit Us - www.researchjournal.co.in

DOI : 10.15740/HAS/JJAE/7.2/323-327

\title{
Water excess/deficit studies at different seasons (bahars) of pomegranate (Punica granatum L.) cultivation
}

\section{ARUN BHAGAT AND MANGAL PATIL}

Received : 06.03.2014; Revised : 28.07.2014; Accepted : 11.08.2014

See end of the Paper for authors' affiliation

Correspondence to :

\section{ARUN BHAGAT}

Department of Irrigation and Drainage Engineering, Mahatma Phule Krishi Vidyapeeth, Rahuri, AHMEDNAGAR (M.S.) INDIA Email : arunbhagat02@gmail.com
- ABSTRACT : The task of monitoring and controlling the field water balance is valuable for efficient management of water and soil which is required for the assessment of long term needs for supplemental irrigation, drainage and water utilization, establishment of certain soil-moisture-plant relationships and determination of optimum crop management practices. The study was carried out to estimate water surplus and deficit for 14 stations of Solapur district of Maharashtra for the period (1977-2007). The result reveals that the percentage maximum water deficit weeks was observed in Malsiras fallowed by Akluj and that of maximum surplus weeks was observed in Solapur followed by South Solapur for every pomegranate bahar for mature $\left(5^{\text {th }}\right.$ years $)$ pomegranate trees.

GEY WORDS : Water excess, Water deficit, Water balance, Bahars

— HOW TO CITE THIS PAPER : Bhagat, Arun and Patil, Mangal (2014). Water excess/deficit studies at different seasons (bahars) of pomegranate (Punica granatum L.) cultivation. Internat. J. Agric. Engg., 7(2) : 323-327. 